\title{
Point and find: the intuitive user experience in accessing spatially structured dialect dictionaries
}

\author{
Eveline WandL-Vogt \\ Institut für Österreichische Dialekt- und Namenlexika (I DINAMLEX), \\ Wohllebengasse 12-14/2, A-1040Wien,Eveline.Wandl-Vogt@oeaw.ac.at
}

\section{SCN III/1 [2010], 35-53}

Članek predstavlja dolgoročni projekt izdelave avstrijskega akademskega narečnega slovarja bavarskih narečij v Avstriji - Wörterbuch der bairischen Mundarten in Österreich (WBÖ). Projekt DBÖ-Datenbank der bairischen Mundarten (Podatkovna baza bavarskih narečij) se je pričel leta 1993 in je bil namenjen digitalizaciji arhivov. Leta 1998 je bil objavljen načrt racionalizacije, katerega cilj je bil dokončanje slovarja do leta 2020 kot (virtualne) enote, sestavljene iz natisnjenega slovarja in komplementarne podatkovne baze.

Izsledki projekta elektronsko kartografirane podatkovne baze bavarskih narečij v Avstriji - dbo@ema kažejo, kako lahko poenotenje spletnih slovarjev in podatkovne baze izvirnih materialov z vizualnim dostopom do georeferenčnih aplikacij in s t. i. topografskimi navigacijami poveča uporabnost in vodi $\mathrm{k}$ večjemu interdisciplinarnemu vpogledu.

This article adresses a long-term project of the "Austrian Academic Dialect Dictionary" the "Wörterbuch der bairischen Mundarten in Österreich (WBÖ / Dictionary of Bavarian dialects in Austria)". The project Datenbank der bairischen Mundarten (DBÖ / Database of Bavarian dialects in Austria) commenced in 1993 and was aimed at the digitalisation of the archives. In 1998 a rationalisation concept was issued, which targeted the completion of the dictionary in 2020 as a (virtual) unit consisting of the printed dictionary and a complementary database.

The project Database of Bavarian dialects in Austria electronically mapped (dbo@ema) has demonstrated how the unification of online dictionaries and source material databases with visual, geo-referenced access applications and so called 'topographic navigation' can increase usability and lead to greater interdisciplinary insight.

Ključne besede: narečna leksikografija, jezikovno katografiranje, potrebe uporabnika, topografska navigacija

Key words: dialect lexicography, language mapping, user needs, topographic navigation 


\section{Preliminaries}

Dialect dictionaries are a special type of dictionary. Academic, highly sophisticated dialect dictionaries are usually long-term projects. A single entry contains more or less encyclopaedic information, not just linguistic details. These dictionaries demonstrate the important role the mother tongue, which is a dialect for many people in Austria, plays in culture and identity.

Consequently, many people are highly interested in dialect(s), meanings of words, and derivation. Unfortunately, scientific dialect dictionaries often do not meet these users' needs.

Dialect dictionaries are costly and often edited over a very long period of time (c.f. Schweizerisches Idiotikon since 1881, Schwäbisches Wörterbuch 1901-1936, Rheinisches Wörterbuch 1928-1971, Siebenbürgisch-sächsisches Wörterbuch since 1924, Wörterbuch der bairischen Mundarten in Österreich since 1963, Sudetendeutsches Wörterbuch since 1988). Therefore, dialect dictionaries often pass through entire eras.

This article discusses how traditional dialect dictionaries could become more user-friendly by on-line publication and by the application of Web GIS.

\subsection{An example: Wörterbuch der bairischen Mundarten in Österreich (WBÖ) / Dictionary of Bavarian dialects in Austria}

To discuss the possibilities of a web GIS in dialect lexicography I choose the example of the WBÖ. This dictionary is a very traditional, long term academic project, yet it tries to apply digital solutions facing a cyber future. While very specific solutions were found for this particular project (cf. 1.1.1, 1.1.2., 1.1.3), some of them might be applicable to similar projects in analogue situations.

\subsubsection{Background: Major Steps into the Digital Age}

In 1911, nearly one hundred years after the first papers on the Bavarian language by Schmeller appeared, the "Kommission zur Schaffung des ÖsterreichischBayerischen Wörterbuches und zur Erforschung unserer Mundarten" was founded by the institution today known as the Austrain Academy of Sciences $(\ddot{O} A W)$ in collaboration with today's Bavarian Academy of Sciences (BAdW). They initiated a new project introducing novel standards in lexicography, which were intended to give a complete and detailed overview of the Bavarian dialect variants in the Austrian-Hungarian Monarchy and the Kingdom of Bavaria, by presenting the complete lexicons of these areas with detailed definitions and contextualized examples, by recording the authentic pronunciation, by defining the grammatical coding for each word entry, by tracing the etymology of each lexical item and by registering expert knowledge in the fields of rural techniques, traditional folk medicine and customs. 
In 1913, after a period of conceptualization, the institute that is today known as the "Institut für Österreichische Dialekt- und Namenlexika (I DINAMLEX)") Institute of Lexicography of Austrian dialects and names was founded and the collection of the material for the dictionary commenced. From 1913-1932 109 questionnaires and 9 auxiliary questionnaires with approx. 24,000 detailed questions were sent to selected municipalities.

In 1961 the Austrian and Bavarian Academy decided to publish two separate parts of the lexicon: Part I dealing with Austria (with the exception of the province of Vorarlberg) and the (former) German-speaking parts across the current borders of Italy, Slovenia, Slovakia, Hungary and the Czech Republic (c.f. Straffungskonzept [1998]: §1), and part II dealing with the Bavarian dialects in Germany. Part I, the $W B \ddot{O}$, has been published since 1963 (4 volumes, 6 parts: $A$ - Twasper) and is intended to comprise 12 volumes by the time of its completion in 2020 (Details c.f. WBÖ 1: V-XVI and Bergmann [2003]).

In 1993 the project "Datenbank der bairischen Mundarten in Österreich (DBÖ)" / Database of Bavarian dialects in Austria was initiated aiming at the digitalisation of the material for the dictionary and of source material (e.g. paper slips, cited texts) as well as background information (e.g. cv of collectors and co-workers).

In 1998 a rationalisation concept was issued targeting the dictionary as a (virtual) unit consisting of the printed dictionary and the complementary database. In 2008 the first step in the development of the system "Datenbank der bairischen Mundarten in Österreich" / Database of Bavarian dialects in Austria electronically mapped (dbo@ema) was taken.

\subsubsection{The dictionary: WBÖ-architecture in a nutshell}

The $W B \ddot{O}$ is a highly sophisticated dialect dictionary. Fig. 1 demonstrates a typical $W B \ddot{O}$-entry (details concerning $W B \ddot{O}$-architecture c.f. Wandl-Vogt [2005a] and [2005b] and supplement 2: 14-17).

The main positions of the $W B \ddot{O}$-entry, with special emphasis on spatial data and cross references due to their navigational potential in electronic versions, are:

- Grammar

Every entry informs about the Grammar of the certain word. Grammatical information is location-dependent.

- Etymology

Every entry contains information about the etymology of a word.

In this position you might find cross references to other dictionaries (e.g. etymological dictionaries) or information about loanwords (and therefore cross references to other dialect dictionaries). 
- Definition(s)

Definitions are the main part of the $W B \ddot{O}$, which is an onomastic dictionary. A lot of examples of spoken and written dialect, phrases, songs and poems are presented. Due to the fact, that approximately $10 \%$ of the material are excerpts of written texts and that the main aim in the beginning was to document the development of a word from its beginning to the actual dialect (c.f. "Arbeitsplan" workplan [1912]) the emphasis on written texts is very high and the $W B O \ddot{O}$ to a good extent represents a historical dictionary as well.

Furthermore, definitions often include a lot of encyclopaedic information about rural traditions and traditional customs.

Every information unit in this position is location-dependent. Information units dating to the $19^{\text {th }}$ century and earlier are - usually exactly dated as, if possible.

- Cross references to other dialect dictionaries of adjecent German dialects Several dialect dictionaries of adjecent German dialects are quoted in every main article: Bayerisches Wörterbuch, Sudetendeutsches Wörterbuch, Vorarlbergisches Wörterbuch, Schwäbisches Wörterbuch, Schweizerisches Idiotikon.

This position is very static in a traditional dictionary, yet it demonstrates how old the idea of hyper-linking in dictionaries is as well as the potential of new media and navigation tools.

- Phonetics

Phonetics played an important role in the so called "Junggrammatische Schule". The dictionary was established in this methodological tradition.

In the meantime, phonetics have become less important than in the beginning of the work on the dictionary partly due to the "Straffungskonzept 1998" (c.f. Straffungskonzept [1998]), but the phonetic realisation of every word in every cited area is still quoted. This increases the amount of challanges, stemming from the specific $W B O ̈$-internal transcription system that is not IPA-based, which have to be solved.

- Compounds

Compounds are treated within the base word entry, e.g. (Unter)drittel is dealt with in the position 'Komp.' (compounds) in the main entry Drittel, c.f. Fig. 1. This nesting might cause problems when a word is searched for and if there are two or more similar base word entries e.g. Tüppel I 'dowel' (WBÖ 5,1075f.), Tüppel II ‘blain' (WBÖ 5,1078f.), Tüppel III ‘money' (WBÖ 4,1086f.), Tüppel IV 'training area, vagabond' (WBÖ, 5,1087) and Tüppel V 'hit' (WBÖ 5,1087).

- Cross references to derivations and related words

There is a position, where cross references to derivations and related words are stored. This is interesting for people searching for word families and studying derivation structures. 


\section{Tritt-dâr-ein, Schwerfällige(r), $\rightarrow$ (dâr-ein)trëten}

\section{Drittel, (Dritt)tēil, (Dritt)tēile}

N. (doch M. obGurkt., WSteir.Wb. 316, Fersent.Wb. 68 , mehrf. hist.; s.a. $\rightarrow T e \bar{e} i)$, d. dritte Teil, Drittel verbr. m. SI, Zugscheit verbr. (bes. OÖst.), Ringstock d. Hirten sMBgl.; Etym.: mhd. dritteil d. dritte Teil bzw. m. abgeschwächtem zweitern Wortteil drittel, Näh. s. DWB 26,1404 f. (Dritteil) u. 1405f. (Drittel); zur Entw. -tēil >-tel vgl, u.a. ${ }^{-\rightarrow}$ Achtel, Fiertel. - Bayer.Wb. 1,564 (Drittel), 1,600 (Dritt-tail), Suddt.Wb. 3,383, Vlbg.Wb. 1,620 , Schwäb.Wb. 2,394, Schweiz.Id. 12,1535f. (Dritt-teil).

Ltg .: Sg.: $m$. noch deutl. erkennbarer Vollform $d$. zweiten Wortglieds (s.a. Etym., hist.Bel.): dritopl (neben dritl) nwestl.obMühlv., dritopü m-,nöWeinv., drital öSMä., drittol Sieb.Gm., drittovile (m. Dat.Suff. od. Dem.Suff.) Gott.; m. Abschwächg. zu $-t l$ : drit $(t) l$ u.ä. verbr., Fersent., Plad., Gott., Brünn; Pl.: dritl verbr., $-n$ ve. Auss.Ld., nwOSt. u. NÖ, W., nöSMä., dritlp mObMurgeb., Paltent., drittle Plad.; Dem.: dritol SMä.

B e d : 1. E. Teilstück v. drei (annähernd) gleichen, gleichwertigen, gleich großen u.ä. Teilen verbr., Sieb.Gm., Fersent.Wb. 68, Plad.Wb. 150, Gott., Brünn; e. D. davon gehört mir, jeder kriegt e. D. u.ä. verbr.; im bes. als Maßang.: a) Flächenmaß: $30 \mathrm{Ar}$ söSMä. Suddt.Wb. 3,383; - †b) Getreidemaß: Tisner dritl 42 mutt und 2 kleine stär vogtfutter Burggr. (1315/c.Anf.17.Jh.) Ö.Weist. 5/1,171; bei dem alten maas, das dritl genant . . und drei dritl ain Bozner kornstar sein Burggr. (1736) Ö.Weist. 5/1,183; - †c) v, zu entrichtenden Abgaben, Bußen, gesetzl. festgelegten Einkünften u.ä. hist. häufig, z.B.: bei Güterwechsel v. Untertanen zu bezahlender dritter Teil d. Wertes der Vermögensmasse Steir.Wb. 171 (wohl hist.); s.a. $\rightarrow$ †(Drittel)puch; sol im daz trittail von gefallen soll ihm das D. davon zufallen Dunkelstn.Wd. (14.Jh.) Ö.Weist. 9,409; all nucz vnd Rennt sullen den drein Herren gleich zusteen, yedem ain drittail W. (1454-64) FRA II, 7,152; wo ainer pein [Knochen] find im vorsst . . geburt der tritl [des Fundguts] dem finder, den andern tritl dem vorsster und der dritt tritl der oberigkait nwTraunv. (1547) Ö.Weist. 13,428; den haarzehent [Flachszehent] gibt man des sontags nach st. Merten, davon nimt der pfarrer den drittail Schneebg.Geb. (1597) ebd. 7,336; Aus obiger straff solle ain dritl der herrschafft, ain dritl dem gericht, und ain dritl dem ansager gehörig sein uEisackt. (17.Jh.) ebd. $5 / 1,229 ;$ ob ainer den andern ze tot schlecht, so ist ainer . . verfallen .. der herrschaft leib und guet auf gnad, ausgenomen das man seinem weib iren drittel [sc. Erbteil] hindan soll geben Kaunert. (1624) ebd. 3,309; s.a. DRW 2,1125f. - 2. Teil d. Zuggeschirrs: das am großen Waagscheit hängende kleine Zugscheit, das an beiden Enden Haken (auch Ringe, kurze Ketten m. Querriegel [ $\rightarrow$ Knebel]) hat, an die d. Zugriemen gehängt werden (die gesamte, a.d. Deichsel befestigte Waage besteht aus drei Querhölzern, d. Waagscheit u. zwei Zugscheitern) ve. Brixent., Leukent. u. obGurkt., verbr. St. u. NÖ, W., Bgl., uBöW, SBö., SMä. (auch Dem.), Brünn, auch Suddt.Wb. 3,383; s.a. DWA 9,10, mehrere Abb. i.d. DBÖ; hist.: Drittl Preßb̄̄.Id.(1787) 67; Syn. $\rightarrow$ (Ort)scheit, (Zug)- (w.d.); s dritl åm bfloßtp nōxšläfn loßn W.; sä šdād (sei still), sunsd nim is dritl und $d p s ̌ l o g g$ di W.; is wieda amul wou a Kipfn o(b) [abgebrochen] oda a Trittl da(r)hin sBgl. NEUBAUER (1962) 7; dass. auch als $\rightarrow$ (Stangen)Steir.Wb. 569, (Wâg)- ve. swTraunv., nwWaldv. u. mWeinv., (Wagen)- ve. mMSt., nöOSt., NÖ, W. bzw. nach d. Vorrichtg., an der d. Zugriemen befestigt sind, als (Hâken)nHausrv., obPielacht., nwWaldv., W., (Knebel)- sWSt., nHausrv., obPielacht., nWaldv., (Ring)- sWSt., nHausrv., nöWaldv., W. 3. Ringstock der Hirten (Stock m.e. Eisenring, in dem kleinere Ringe eingehängt sind) sMBgl. HBl.Bgl. 21 (1959) 3,210 (zum Sachl. ebd. 215f.); Syn. $\rightarrow$ (Klinsel)kolben (Ring)stëcken. - 4. Maß b. Kugelspiel, s.u. $\rightarrow$ Tritt 4c.

Ko m p. (s.a. $\rightarrow$ Simpl.2): (Unter)-: Bez. für die talauswärts liegenden (annähernd e. D. der Gemeinde ausmachenden) Weiler v. Ischgl obPazn.

Abl. $\rightarrow$ dritteln; weiters: (Unter)drittler, M., Bewohner der talauswärts liegenden Weiler von Ischgl ( $\rightarrow$ [Unter]drittel) obPazn.; Drittling, M., kleines Zugscheit sMBgl. DWA 9,10 .

\section{dritteln, †(dritt)tēilen}

sw.Vb., 1) in drei Teile teilen, dritteln ve. (dritln u.ä. verbr., drittl[ən] Tir.Wb. 1,135); hist.: haben wier ganzen zechent und wo mit un $\beta$ zu drittailen ist, da nimbt deß pharrer anwalt den selben drittail . . ein uMürzt. (15.Jh.) Ö.Weist. 6,$302 ;-2$ ) b.e. Zweigespann, bei dem ein Pferd stärker ist als $d$. andere, das

Figure 1. Example-entry: WBÖ 5, 546-547. 
- Included articles of

- Compounds

Compounds are often not dealt with in the separate position for compounds but within the entry's definitions, e.g. (Wâg)drittel, (Wagen)drittel, (Hâken)drittel, (Knebel)drittel, (Ring)drittel c.f. Fig. 1 (definition 2). These compounds are usually enriched with spatial information and an indirect definition (same definition as the simplex definition), sometimes even phonetics.

- Derivations and related words

Derivations and related words with "less information value" due to "Straffungskonzept" (c.f. Straffungskonzept [1998] §§ 1.2.1-1.2.3) are often dealt with in the position itself, e.g. Drittling c.f. Fig. 1 (position 'Abl.'). Furthermore, they sometimes also represent compounds, e.g. (Unter)drittler, c.f. Fig. 1 (position 'Abl.').

- Editor

Finally, in the end the author of the entry is mentioned with her / his initial, e.g. W.B. $=$ Werner Bauer.

Due to the ambitious scientific aims, a lot of abbreviations and a quite dense and rich text, the dictionary itself can (unfortunately) hardly be used by laypersons.

\subsubsection{The dictionary: Access structures, visualisations and user needs}

The main access structure of the $W B \ddot{O}$ is the macrostructure, namely the headword. Yet due to etymologic-historic considerations the headword can hardly be used as access structure by scientists and in particular not by laypersons. E.g. the standard German headword deutsch ('german') is represented in the WBÖ as teïtsch; the standard German headword Pflaumenbaum, standard Austrian Zwetschkenbaum ('plum tree') is represented in the WBÖ as (Zwëtschken)päum and a subentry of the main entry Päum ('tree').

Concerning the concept and the collection of the material, visualisations played an important role in the compilation of dictionary, but due to rationalisations they never were printed or published as planned or as it was aimed. There are just a few published maps in the first volume of the $W B \ddot{O}$, although the original intention was a ratio of 1:3: "Im Bedarfsfall [werden] Skizzen von Geräten und ihren Teilen sowie wort- und lautgeographische Kärtchen zur Entlastung des Artikeltextes" [beigegeben]. [If necessary drafts of machines and their parts as well as maps with linguistic details are added to keep the entry precise and clear.]

There are no studies on the users of the dictionary; therefore no specific information about them is available. One mostly has a German speaking scientific user in mind, yet Austrian laypersons are very interested in dialect as well. Especially the dialect of the region one has was grown up in or of one's 
hometown is quite interesting to people. Questions such as 'What could you tell me about the dialect of my hometown?', 'What does your material show me about my hometown?', 'What literature could I consult, when researching the dialect of this region?' shall hence be subsumed under the headword 'geographically focussed interest'.

Unfortunately, due to its very sophisticated scientific architecture, the dictionary hardly meets user needs in general and - in particular - cannot meet the user's 'geographically focussed' needs.

\section{Spatial data}

\subsection{Come together: About spatial data in lexicography and in geo-informatics}

So called 'geographically focussed interest' is met by the addition of spatial data to a dictionary. Unfortunately, in a printed dictionary the addition of spatial data does not increase the usability of the dictionary itself.

Digital dictionaries could use this spatial information and become something novel between dictionary and linguistic atlases. Geo-informatics is the discipline to establish navigation based on spatial data.

\subsection{An example: Spatial data in the database (DBÖ) and the dictionary (WBÖ)}

All the collected data includes specific details on the place of origin (georeferences) and thus documents a certain headword in a specific definition and geographic location (e.g. Fig. 2: Wien Sievering [a borough in Vienna / Austria]).

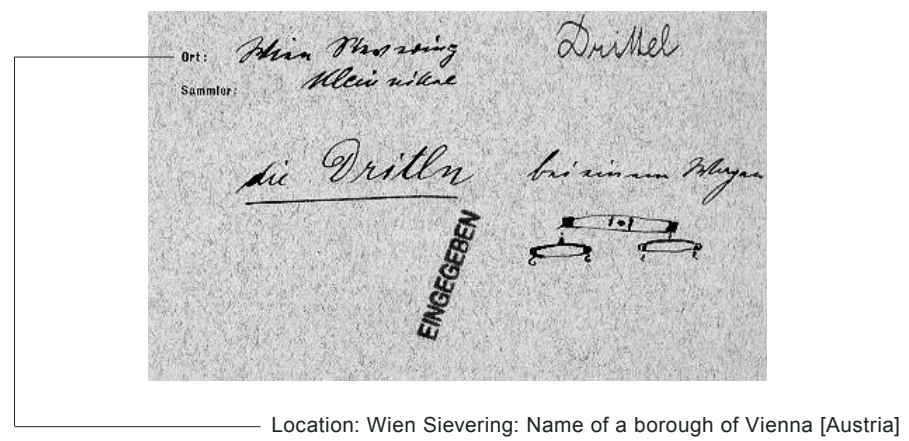

Figure 2. Example: Paper slip of the main archive with spatial data

Furthermore spatial data is important within the architecture of dialect dictionaries. In the $W B \ddot{O}$, every single information unit is lexicographically pinpointed: phonetic realisations as well examples of written or spoken language, information about ancient customs as well as definitions themselves. 
Yet, due to their heterogeneity some problems concerning the localisations in the base material as well as in the dictionary and the database arise. Some of the most prominent problems should be mentioned.

There are several types of localisation information that cause problems when trying to map them:

- Directly defined, aerially precisely circumscribable localisation information This localisation information is well defined on the areas of municipalities. E.g. obGurkt. (oberes Gurktal); definition: upper part of the valley of the river Gurk in Carinthia consisting of the municipalities Albeck, Deutsch-Griffen, Glödnitz, Gurk, Straßburg, Weitensfeld im Gurktal (c.f. Fig.1; definition c.f. supplement 2: 167)

- Directly defined, aerially diffusely circumscribable localisation information This localisation information can not be well defined due to it's specific character; yet to be mapped anyway it is on the one hand defined on the base of municipalities (as far as linguistic areas are concerned) and on the other not taken in account for mapping (as far as general localisation information is concerned).

E.g. 'verbr.' (verbreitet); definition: usual, everywhere well known in the Bavarian speaking area without linguistic enclaves (c.f. Fig.1; definition c.f. supplement 2: 185)

- Indirectly defined, aerially circumscribable localisation information This localisation information is aerially defined on the base of municipalities, yet the information itself is given by an author of cited literature. This might cause differences, mainly concerning spatial development during time.

E.g. 'WSteir.Wb.' (c.f. Fig. 1): definition: dictionary about the regional dialect of the Western Styrian area, yet it might not be completely the same area that the author meant with Western Styrian area as the definition in supplement 2: 187 is, yet this might be checked in the preface of the dictionary.

E.g. 'Burggr. (1315/C.A.17.Jh.) Ö.Weist. 5/1,171' (c.f. Fig. 1): Problems increase, when dealing with historical texts as this example shows. This is the quotation of a copy of a historical document of the early $14^{\text {th }}$ century, copied in the early $18^{\text {th }}$ century, edited in the $20^{\text {th }}$ century (and cited from this edition). What is documented: the "dialect" of the writer or the dialect of the area? How much does it differ? To solve these problems, one could and should do much cross-disciplinary teamwork with historians to find good solutions for dealing with similar problems and to increase the quality of the dictionary's quotations.

To handle geo-referencing and to enable the mapping process, spatial information concerning the dialect dictionary has to be systematised (c.f. Wandl-Vogt [2006a], Wandl-Vogt [2006b]).

As far as this localisation types are concerned, the $D B O \ddot{O}$ consists of several types of regions: 
- Administrative regions

These regions are formed by the valid tree of regions, based on administrative units, here: municipalities.

E.g. oberes Paznaun - Paznaun - Westtirol (Western Tyrol) - Nordtirol (Northern Tyrol) - Tirol (Tyrol) - Österreich (Austria) (definitions for the several areas c.f. supplement 2: 168, 172, 188, 164, 179)

- Special $W B O ̈$ regions

These regions are especially necessary for the dictionary writing process. They are defined to keep the dictionary entry clear and short.

E.g. Ennstal consisting of a Styrian part (steirisches Ennstal) and a part (valley) in Upper Austria (Oberösterreichisches Ennstal) and Lower Austria (Niederösterreichisches Ennstal). Furthermore there is a part that people might call Ennstal in the county of Salzburg (Ennspongau) (definitions for the several areas c.f. Beiheft 2: 155, 176, 170, 162, 155).

- Linguistic / dialectological regions

These regions are directly defined, yet just diffusely circumscribable localisation information forming the Austrian dialect area. They are based on municipalities as well as on mapping.

E.g. Südbairisch (Southern Bavarian) as the most conservative dialect area in Austria. (definition c.f. supplement 2: 173).

- Cross-reference regions

These regions are not used in the dictionary, but are important enough to be stored in the database. They might be geographical names that are used in the dictionary with a special circumference (e.g. Heideboden consisting of an Austrian part in Burgenland and a Hungarian part; definition c.f. Beiheft 2: 156) or they might be special names that are well known in Austria (and maybe even used in former parts of the dictionary but not used again) (e.g. Jogelland a part of Eastern Styria; definition c.f. supplement 2: 157).

\subsection{GIS and web GIS versus maps: an additional benefit analysis}

Analysing both, material and dialect dictionaries, it can be shown that spatial data is available, yet usually not applied for navigation needs in online dictionaries and were until now generally not regarded as a point of interest as far as dialect dictionaries are concerned. There are of course dictionaries and dialect dictionaries working with maps and geo-referenced data. As Hald Pedersen and Eske Rasmussen (2007) show with the example of Gyldendals Online Leksikon, dictionaries and online atlases can come together and visualisation tools can increase the dictionary's usability.

A Geographic information system (GIS) is an information system by the means of which geo-referenced data can be digitally recorded and edited, saved and reorganised, shaped and analysed as well as alphanumerically and 
graphically presented. A web GIS represents such a tool that is usable in the www (about the web GIS concept, standards and benefits c.f. Bartelme [2005] 403f.). A web GIS should enable the user herself / himself to create maps based on her / his own and personalised queries.

Selected examples demonstrating some of the features are to be discussed:

2.3.1 An example: Mapping to see several types of regions - Maks Pleteršnik: Slovensko-nemški slovar (1894/1895)

This old German-Slovenian dictionary was digitalised by scientists of the Academy of Slovenia situated in Ljubljana and published as CDR in 2006.

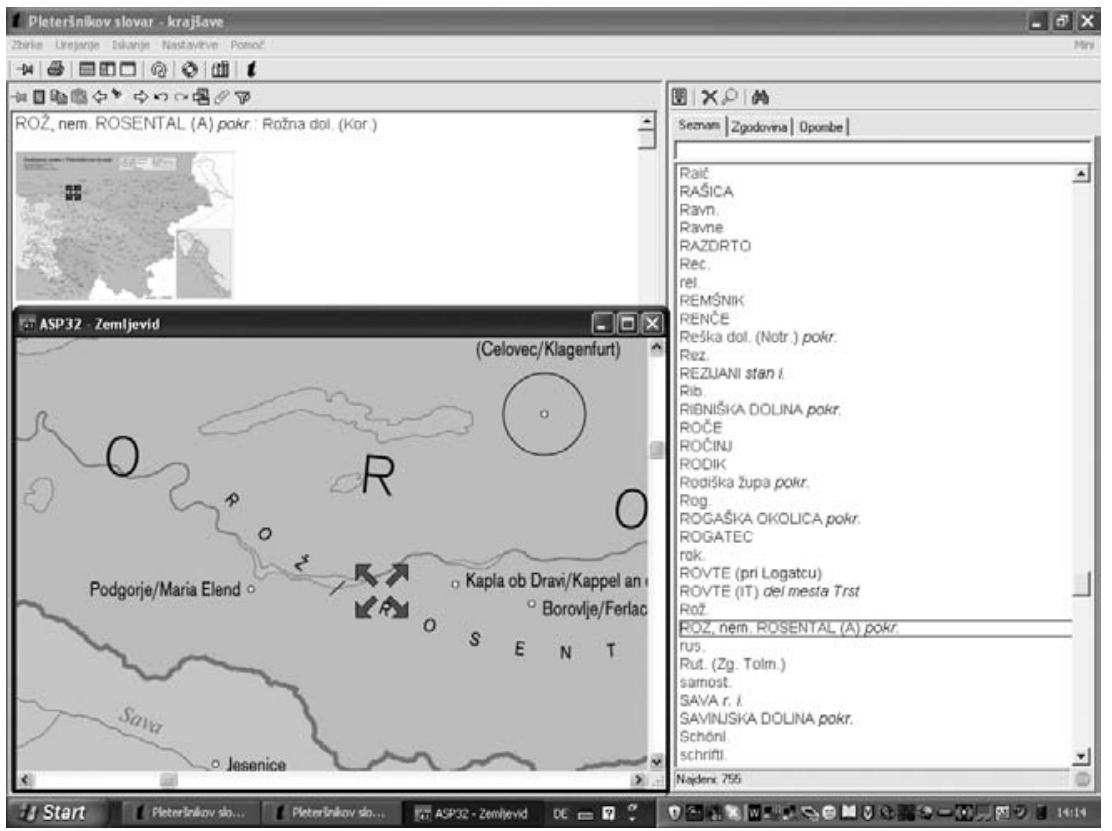

Figure 3. Example: Screenshot of the Pleteršnik-CD

The maps show the locations mentioned in the dictionary. Localisations are typed somehow similar to the $W B \ddot{O}$ and $D B \ddot{O}$.

E.g. Rož / Rosental is an area that is diffusely circumscribable; Celovec / Klagenfurt is a point that is well defined, aerially well circumscribable.

This map might be helpful when working with the historical dictionary to locate areas or cities in a current map, unfortunately one can only navigate from the register to the map and not from the map to anywhere else. Maps like these need certainly not be geo-referenced. 
Yet, geo-referencing could increase the usability and quality of such digital dictionaries and maps as is to be demonstrated later (c.f. 3).

\subsubsection{An example: Mapping to navigate to a dictionary Digitaler Verbund von} Dialektwörterbüchern / Network of dialect dictionaries

The Network of dialect dictionaries is a DFG-project (Deutsche Forschungsgemeinschaft) that has been running since 2003 at Trier University. The main aims of the project are the digitalisation and cross-linking of several dialect dictionaries. At the time being, 4 dictionaries are included, namely Rheinisches Wörterbuch, Pfälzisches Wörterbuch, Wörterbuch der elsässischen Mundarten and Wörterbuch der deutsch-lothringischen Mundarten, (c.f. website).

In this project the map - one can choose a physical map or a map of dialect areas - is used to access a special dialect dictionary. If one does not know which dictionary deals with the area of interest, it represents a helpful tool. Yet, it does not help at all in dealing with the dictionary's content. Furthermore, there is no need for such a map to be geo-referenced.

A new project deals with the cross-linking of maps in the dictionaries with other (geo-referenced) data, namely DiWA. This might certainly increase the quality of both, dictionary and online atlas. To link data and maps, georeferencing of data is necessary.

\subsubsection{An example: Mapping to see and labelling spatial data to increase handling - The English Dialect Dictionary (EDD)}

The SPEED-project (Spoken English in Early Dialects), is a FWF-funded project, running at the Leopold-Franzens University of Innsbruck since 2006. It aims to produce an online version of Joseph Wright's English Dialect Dictionary (1898-1905).

The mapping tools applied in this project will be scientifically discussed in the theses of Praxmarer. Furthermore, labels referring to several levels of location (nations, regions, counties, parts of counties) shall be available in the online version. This enables the user to find articles on a certain place of interest and thereby represents a navigation tool which meets user needs.

At this stage of development, geo-referenced mapping could easily be applied to increase the possibilities and enable the user to create maps on her / his own.

Furthermore, Praxmarer (2008) demonstrates, by the example of the EDD, an attempt to use thematic maps and simple calculations to attain a better understanding of the relationship between the different English dialects, which is not provided by the dictionary itself. So in this case, geo-referencing is not just used for mapping but also for analysing data. 
2.3.4 An example: Mapping to get to data - The Online Dialect Atlas of Newfoundland and Labrador English (DANL) and Australian Word Map

This Atlas project, running at the Department of Linguistics at the Memorial University of Newfoundland, aims to provide insight into the regional distribution of linguistic features, lexicon, phonology and morphology. It is planned to be accessible to scholars as well as the general public.

On the one hand, the mapping of linguistic features is aimed at and on the other hand access based on geo-referenced data shall be established. By way of locations it is planned to enable users to access data.

An example for this, in a very humorous and user friendly way, is the Australian Word Map. One can click anywhere on the map to highlight a geographic region of ones choice and to search for regionalisms, words, phrases or expressions used in particular parts of Australia. Then one can navigate from the regionalisms to get further information.

This is a new concept of presenting dialect data, similar to that described in Wandl-Vogt [2006a $+2006 \mathrm{~b}]$ for a dialect dictionary. Geo-referenced data becomes part of the navigation structure.

With this, geo-referencing leads to increased quality and usability.

\section{An example: From the data to the map - from the map to the data}

Datenbank der bairischen Mundarten in Österreich I

Database of Bavarian dialects in Austria electronically mapped (dbo@ema)

\subsection{Background information: Main aims}

The projectdbo@ema starts, where most of the above mentioned examples end: The material stored in the $D B O ̈$ is standardised, geo-referenced, stored in a database and mapped. The resulting web GIS application enables users to query and scroll the database and dictionary contents by, e.g. intuitively clicking locations or areas in maps shown in their browser.

The projectdbo@ema is financed by the FWF (Austrian Science Fund) and ran for 36 months (02.2007-11.2009). It was initiated and situated at the $I$ DINAMLEX, while at the same time representing a cross-disciplinary project between lexicographers, computer linguists and computer scientists of the Alpen-Adria Universität Klagenfurt and Technische Universität Graz, both in Austria, as well as the Philipps-Universität Marburg (Germany). 


\subsection{Under construction: The database and the web GIS - First results}

\subsubsection{The database}

The new system is based on MySQL. There is one database and several tables storing data of specific provenience.

The main part of the database contains the information of the digitalised paper slips. Several tables store background and source material information.

The part of the database that has been newly developed since 2007 is the handling of user administration and user management. This will increase the quality of the entries as well as the usability in doing research based on the dictionary's base material.

Important in respect to internal and external cross-references are the lemma tables. These tables were re-structured and re-designed to comply to the user needs concerning the compilation of the $W B \ddot{O}$ entries under the leadership of the author.

Finally, the location tables were re-structured and re-designed to a very high degree and in a very sophisticated way to meet the user needs of the dictionary compilers. First a location system that is based on municipalities was established (c.f. 2.2). This on the one hand allows to build a specific system for the $W B \ddot{O}$ and on the other creates the possibility to enlarge the database with ones own data, based on municipalities. The system does not only apply to Austria, as is shown by the example of the province of Bolzano in Italy, but also to all other nations one is able to fill geo-data into the system on. So the system is as flexible as possible.

\subsubsection{Web GIS}

The GIS-Application itself is based on and part of the MySQL database.

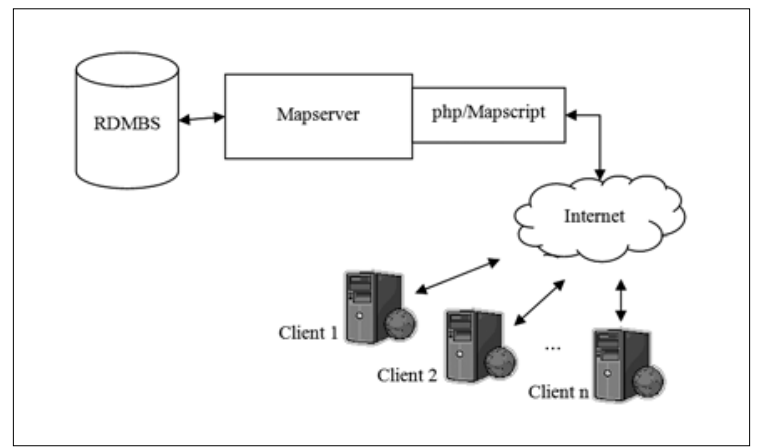

Figure 4. GisApplication: system architecture (overview: developed within dbo@ema by Norbert Bartelme and Johannes Scholz: system under construction) 
The user himself never comes into direct contact with the special software. She / he accesses the data by browsing in the web and might find her / his way to the data by intuitively clicking on the map.

Two Test-Systems to visualise data and to navigate to the database have been established.

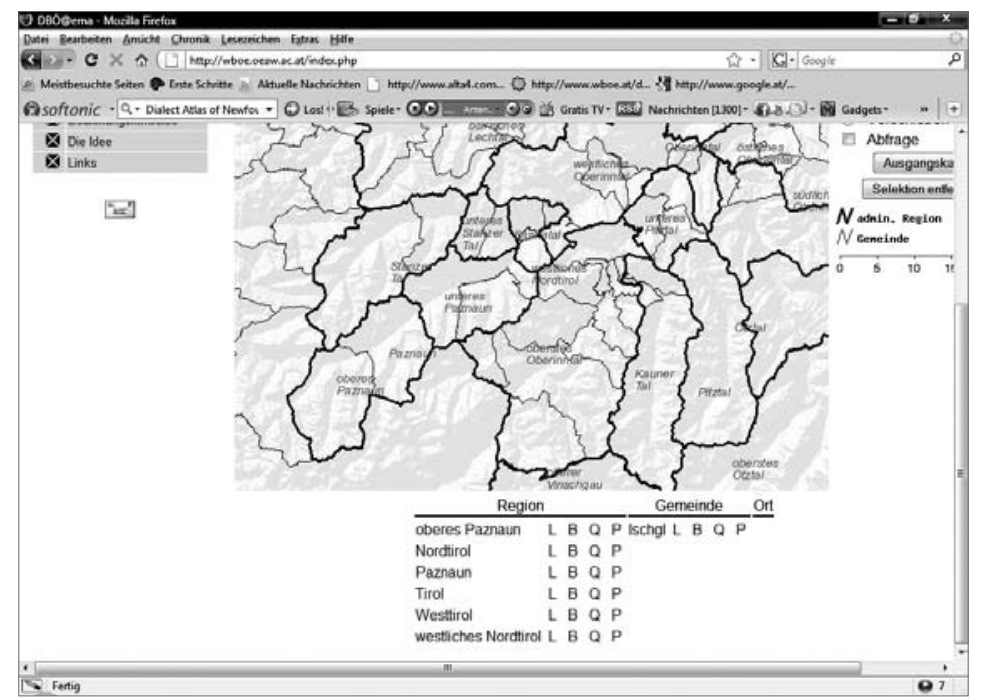

Figure 5a. GisApplication: Visualisation of spatial data with ArcGIS (example: screenshot developed withindbo@ema by Norbert Bartelme and Johannes Scholz: system under construction)

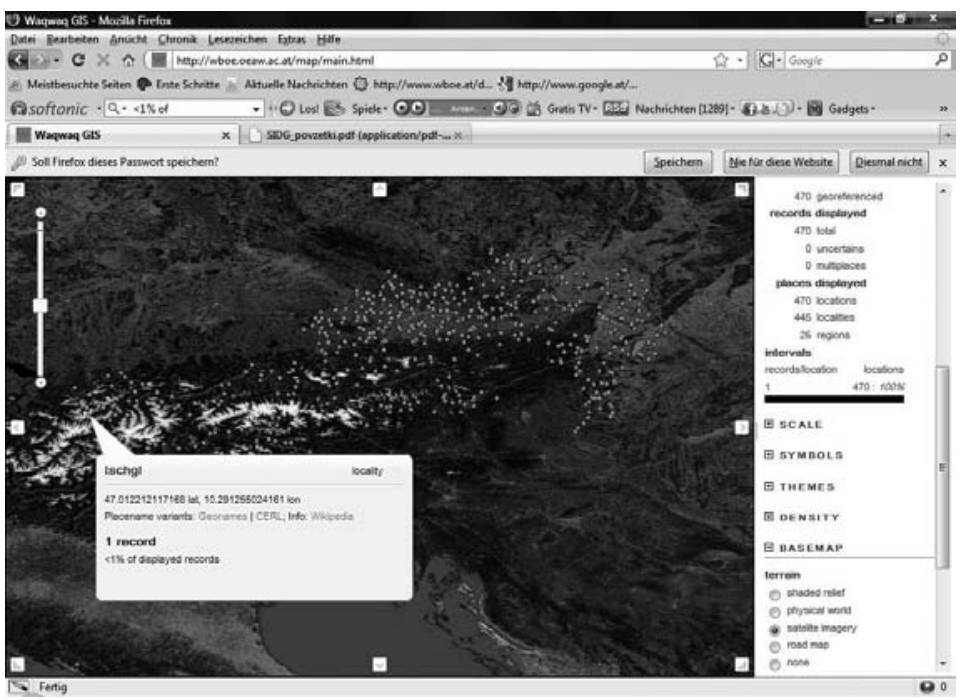

Figure 5b. GisApplication: Visualisation of spatial data with ArcGIS (example: screenshot developed within dbo@ema by Vlad Atanasiu: system under construction) 
These systems offer possibilities that a printed version is not able to realise. On the one hand, one can zoom into the system and surf trough the several hierarchies of location units, from Österreich to the little municipality of Ischgl in the Paznaun in Tirol. Every level is linked with the database information (lemma, paper slip, bibliography, locations), so every query can bring certain information just dealing with the specific location. On the other hand, only the information that interests a user can be shown either on one of the several hierarchical (namely zoomed) levels or one very hierarchical level.

Finally, due to the fact that the whole material is geo-referenced, it can easily be linked with other geo-referenced material, e.g. other linguistic data, demographic data, and archaeological data. This overlay of certain kinds of information could lead to new scientific questions and help us gain novel insights.

A web GIS makes the data available to everybody anywhere. Yet, this flexibility has its price. Web GIS maps are, from a cartographic point of view, less sophisticated than other GIS maps and even less than printed maps. While scripting the computer-aided process one cannot think of all the possibilities the user could create by zooming in and out. But if the user in time will get accustomed to this tool, the tool itself will develop by feedback.

\section{Challenges and chances - Meeting user needs?}

This example demonstrates that digitalisation of material means much more than a kind of archiving. With the digitisation of the base material a new working process concerning the WBÖ-compilation started in the I DINAMLEX. Furthermore, the traditional methods were contemplated on and new levels of quality standards were set, e.g. concerning dating of examples. Finally, a rationalisation concept was issued, conceiving the dictionary and the base material database as a virtual unit. This is, lexicographically seen, a novel approach and influenced the medio-structure of the dictionary completely.

At the time being, the database is starting to become a medium on its own. When the project dbo@ema is finalised and after the input of the complete data of the $D B O \ddot{O}$ into the new system, the data will be returned to the public from where it came from about a 100 years ago.

To meet this aim, there are some challenges that have to be overcome, which were not dealt with in this article:

Firstly, the data includes many specific characters, e.g. the phonetic transcription or the lemma. These characters have to be created. This is realised in the project dbo@ema as well and one can download the font dinamlex (.ttf and .otf) from the project website (http://wboe.oeaw.ac.at) for free. Yet, it will be under construction as long as there are paper slips that have not been digitalised. The many specific characters represent challenges in dealing with queries and research in the data and visualisation on the web.

Secondly, a lot of background information is necessary to understand the specific information of a single paper slip. Usually, this is the lexicographer's 
qualification. The information, that is storable in a database, should be stored in so called documentation databases (e.g. persons - information about their curriculum vitae and their phonetic transcription). This means a lot of sophisticated and specialised work, which in the end will be one of the most important quality criteria of the database.

Further projects could address the cross-referencing of other geo-referenced data and the establishment of further visualisations in the dictionary in order to increase the navigation and to meet user needs, especially those of laypersons.

Furthermore, the database established in the framework of project dbo@ema could be enlarged with material of the I DINAMLEX and with additional material of other dictionaries, to become an online information tool, not just about language, but about dialect as well.

Finally, this kind of database enables the lexicographers to speed the lexicographical compiling process and helps to increase the dictionary's quality in respect to standardisation.

\section{Conclusions - Dialect dictionaries at a crossroads?}

Dialect dictionaries are at a crossroads. Not only because of the possibilities new media and cross-disciplinary cooperation allows. Traditional dialect dictionaries are often not as innovative as other dictionary projects due to the fact that they are huge and long-term projects and always under time pressure to publish. There are a lot of challenges for this type of dictionary to face the future: dialect dictionaries as a very important part of cultural heritage of an area / nation, maybe currently more relevant than ever to provide people with the opportunity to 'come home' and 'find back to the own roots' in a globalised world.

\section{REFERENCES}

\section{A. Dictionaries and online atlases}

Australian Word Map $=<$ http://www.abc.net.au/wordmap// (accessed 14.12.2009)

Bayerisches Wörterbuch = Johann Andreas SCHMELLER, 1872-1877: Bayerisches Wörterbuch. Stuttgart / Tübingen.

DANL $=$ Sandra CLARKE et al. (eds.), to be published: The Online Dialect Atlas of Newfoundland and Labrador English. <http://www.mun.ca/linguistics/research/ nl_english/danl.php>. (checked: 15.08.2008).

Digitaler Verbund von Dialektwörterbüchern = Universität Trier (ed.), 2003: Digitaler Verbund von Dialektwörterbüchern. <http://germazope.uni-trier.de/Projects/ DWV/karte.html> (checked: 01.02.2010). 
DiWA III = Jürgen Erich SCHMIDT et al (eds.), 2001-. Digitaler Wenker-Atlas. Erste vollständige Ausgabe von Georg Wenkers "Sprachatlas des Deutschen Reichs 1888.1923". <http://www.diwa.info> (checked: 01.02.2010).

EDD = Josef WRIGHT, 1989-1905: The English Dialect Dictionary being the complete vocabulary of all dialect words still in use, or known to have been in use during the last 200 years. London: Frowde.

Gydendals Ondine Leksikon = Gyldendal (ed.), 2007-: Online Leksikon. <http:// www.gyldendalsleksikon.dk/leksikon/leksikon.htm> (checked: 15.08.2008).

Pleteršnik = Helena DOBROVOLJC et al. (ed.), 2006: Maks Pleteršnik: Slovenskonemški slovar (1894/1895). Znanstvenoraziskovalni center SAZU. Vse pravice pridržane. CD.

Rheinisches Wörterbuch = Josef MÜLLER et al (eds.), 1928-1971: Rheinisches Wörterbuch. 9 Volumes. Bonn / Berlin. <http://germazope.uni-trier.de/Projects/ WBB/woerterbuecher/rhwb/wbgui?lemid=RA00001> (checked: 15.08.2008).

Pfälzisches Wörterbuch = Ernst CHRISTMANN et al. (eds.), 1965-1997: Pfälzisches Wörterbuch. 6 Volumes. Wiesbaden / Stuttgart: Steiner. $\leq$ http://germazope. uni-trier.de/Projects/WBB/woerterbuecher/pfwb/wbgui?lemid=PA00001 $>$ (checked: 15.08.2008).

Schwäbisches Wörterbuch = Hermann FISCHER / Wilhelm PFLEIDERER (eds.), 1901-1936: Schwäbisches Wörterbuch. Tübingen: Verlag der H. Laupp'schen Buchhandlung.

Schweizerisches Idiotikon = Friedrich STAUB / Ludwig TOBLER (eds.), 1881-: Schweizerisches Idiotikon. Wörterbuch der schweizerdeutschen Sprache. Frauenfeld: Huber.

Siebenbürgisch-sächsisches Wörterbuch $=$ Ausschuß des Vereins für Siebenbürgische Landeskunde et al. (ed.), 1924-: Siebenbürgisch-sächsisches Wörterbuch. Mit Benützung der Sammlungen Johann Wolffs. Köln / Weimar / Wien.

Sudetendeutsches Wörterbuch = Heinz ENGELS et al (ed.), 1988-: Sudetendeutsches Wörterbuch. Wörterbuch der deutschen Mundarten in Böhmen und MährenSchlesien. München: R. Oldenbourg.

Vorarlbergisches Wörterbuch $=$ Österreichische Akademie der Wissenschaften (ed.), 1960-1965: Vorarlbergisches Wörterbuch mit Einschluß des Fürstentums Liechtenstein. Wien: Adolf Holzhausens Nachfolger.

WBÖ = Eberhard KRANMAYER / Kommission für Mundartkunde und Namenforschung / Institut für Österreichische Dialekt- und Namenlexika (eds.), 1963-: Wörterbuch der bairischen Mundarten in Österreich (WBÖ). Wien: Verlag der Österreichischen Akademie der Wissenschaften.

Wörterbuch der elsässischen Mundarten = Ernst MARTIN et al. (eds.), 1899-1907: Wörterbuch der elsässischen Mundarten. 2 Volumes. Straßburg. [New edition: Berlin / New York: 1974.] < http://germazope.uni-trier.de/Projects/WBB/woerterbuecher/lwb/wbgui?lemid=CA00001 $>$ (checked: 15.08.2008).

Wörterbuch der deutsch-lothringischen Mundarten = Ferdinand FOLLMANN (ed.), 1909: Wörterbuch der deutsch-lothringischen Mundarten. Leipzig. [New edition: 
Hildesheim / New York. 1971.] < http://germazope.uni-trier.de/Projects/WBB/woerterbuecher/lwb/wbgui?lemid=CA00001 $>$ (checked: 15.08.2008).

\section{B. Other literature}

Kommission zur Schaffung des österreichisch-bayerischen Wörterbuchs (ed.), 1912: Arbeitsplan und Geschäftsordnung für das bayerisch-österreichische Wörterbuch. Wien. - online: http://www.oeaw.ac.at/dinamlex/WBO [checked: 15.08.2008]

Norbert BARTELME, 2005: Geoinformatik. Modelle - Strukturen - Funktionen. Berlin / Heidelberg / New York: Wichmann.

Institut für Österreichische Dialekt- und Namenlexika (ed.), 2005: Wörterbuch der bairischen Mundarten in Österreich. Beiheft Nr. 2. Erläuterungen zum Wörterbuch. Abkürzungsverzeichnis, Lauttabelle, Artikelstruktur, Literaturverzeichnis, Gemeindenamenregister, Verzeichnis der Gebietsnamen (mit einer Übersichtskarte und 6 Detailkarten). Bearbeitet von Hubert Bergmann, Inge Geyer, Manfred Glauninger, Elisabeth Groschopf, Eveline Wandl-Vogt. Wien: Verlag der Österreichischen Akademie der Wissenschaften.

Hubert BERGMANN, 2003: Streiflichter aus der Geschichte des Instituts für Österreichische Dialekt- und Namenlexika. Wien. - online: <http://www.oeaw.ac.at/ dinamlex/power_point_tagg_copy.ppt>[31.07.2008].

Jacob HALD PEDERSEN et al. 2007: Strategy i navigation. LexicoNordica 14. $71-80$.

Eberhard KRANZMAYER, 1951: Die Arbeit der Akademie am ÖsterreichisschBayerischen Dialektwörterbuch (Organisation und Durchführung, Aufgabe und wissenschaftliche Betreuung). Anzeiger der österreichischen Akademie der Wissenschaften, phil.-hist. Klasse 9. Ed. Österreichische Akademie der Wissenschaften. $113-123$.

Michael NENTWICH, 2003: Cyberscience. Research in the Age of the internet. Wien: Verlag der Österreichischen Akademie der Wissenschaften.

Christoph PRAXMARER, 2010: Dialect relations in EDD. Proceedings of Methods XIII: Papers from the Thirteenth International Conference on Methods in Dialectolo$g y, 2008$. Eds. Barry HASELWOOD, Clive UPTON. Frankfurt: Peter Lang: 153-159.

Johannes SCHOLZ et al., 2008: Mapping Languages - Erfahrungen aus dem Projekt dbo@ema. Angewandte Geoinformatik 2008. Beiträge zum 20. AGIT-Symposium. Eds. Josef STROBL et al. Heidelberg: Wichmann: 822-827.

Institut für Österreichische Dialekt- und Namenlexika (ed.), 1998: Neues Straffungskonzept für das Wörterbuch der bairischen Mundarten in Österreich (WBÖ). Wien: Manuscript. - printed in: Beiheft 2: 11-13. - online: <http://www.oeaw.ac.at/ dinamlex/Straffungskonzept_1998.pdf $>$ [31.07.2008]

Eveline WANDL-VOGT, 2005a: From paper slips to the electronic archive. Crosslinking potential in 90 years of lexicographic work at the Wörterbuch der bairischen Mundarten in Österreich (WBÖ). Papers in computational lexicography. Complex 2005. Eds. Ferenc KIEFER, Gábor KISS and Júlia PAJZS. Budapest: Linguistics Institute, Hungarian Academy of Sciences: 243-254. 
--, 2005b: Überlegungen zur Artikelstruktur im Wörterbuch der bairischen Mundarten in Österreich (WBÖ) unter Berücksichtigung des Neuen Straffungskonzeptes von 1998. Dargestellt anhand ausgewählter Wörterbuchartikel von Günter Lipold. Sprache als System und Prozess. Festschrift für Günter Lipold zum 60. Ed. Christiane M. PABST. Geburtstag. Wien: Praesens: 24-39.

- -, 2006a: Von der Karte zum Wörterbuch - Überlegungen zu einer räumlichen Zugriffsstruktur für Dialektwörterbücher. Atti del XII Congresso internazionale di Lessicografia. Torino, 6-9 Settembre 2006. European Association for Lexicography. Eds. Elisa CORINO et al. Volume II. Alessandria: 721-732.

- -, 2006b: Mapping dialects. Die Karte als primäre Zugriffsstruktur für Dialektwörterbücher. Kartographie als Kommunikationsmedium / Cartography as a Communication Medium. Eds. Karel KRIZ et al. Wiener Schriften zur Geographie und Kartographie 17: 89-87.

--, 2007: An der Schnittstelle von Dialektwörterbuch und Sprachatlas: Das Projekt "Datenbank der bairischen Mundarten in Österreich electronically mapped (dbo@ema)". Germanistische Linguistik Eds. Stephan ELSPASS et al. 190-191: 197-211.

\section{POKAŽI IN NAJDI: IZKUŠNJA INTUITIVNEGA UPORABNIKA PRI DOSTOPU PROSTORSKO STRUKTURIRANIH NAREČNIH SLOVARJEV}

$\mathrm{V}$ prispevku je predstavljen $W B O ̈-$ Wörterbuch der bairischen Mundarten in Österreich (Slovar bavarskih narečij v Avstriji), ki je povezan z DBÖ-jem - Datenbank der bairischen Mundarten in Österreich (Podatkovna baza bavarskih narečij v Avstriji). Pregledu razvoja tega tradicionalnega slovarja od natisnjene izdaje do interaktivnega leksikografskega informacijskega sistema sledi kratek vpogled v slovarsko zgradbo. V osrednjem delu prispevka avtorica poudarja geografsko usmerjeno zanimanje uporabnika. Opredeljuje ga kot situacijo rabe, v kateri je vprašanje o jezikoslovnih in enciklopedičnih vsebinah povezano z vprašanjem o lokaciji, npr.: »Katere ključne besede iz mojega domačega mesta XY so obdelane v WBÖ? « Da bi zadovoljili tako usmerjenega uporabnika, so tipi lokacij (administrativne regije, posebne WBÖ-regije, lingvistične/ narečne regije, referenčne regije), ki jih je uvedla avtorica, opredeljeni v $W B O ̈$ in z njim povezanim $D B \ddot{O}$, s čimer je ustvarjen hierarhično nedvoumen lokacijski sistem, ki pokriva celotno področje dela.

Vse informacije o lokacijah (neposredno opredeljene, arealno natančno omejene informacije o lokaciji [LA]; neposredno opredeljene, arealno razpršeno omejene LA; posredno opredeljene, arealno omejene LA), omenjene v slovarju, so zasidrane v tem sistemu. Kratek pregled rabe kart in (spletnega) GIS v (narečni) leksikografiji prikazuje prehod od narečnega slovarja do spletno utemeljenega sistema s povezavami na spletne strani sodobnih jezikovnih atlasov.

Glavni del analize je posvečen predstavitvi projekta elektronsko kartografirane podatkovne baze bavarskih narečij v Avstriji - Datenbank der bairischen Mundarten in Österreich electronically mapped (dbo@ema), in sicer z vidika dodane vrednosti, pridobljene s topografsko navigacijo. Podatkovna baza MySQL, ki temelji na predstavljenem sistemu lokacij, s prostorsko razširitvijo in sistematično georeferenčno podatkovno bazo predstavlja tako osnovo za prikazovanje podatkov kot tudi podlago za nadaljnje analize gradiva, ki doslej na ta način niso bile mogoče. 